\title{
AL-A'RAF
}

Jurnal Pemikiran Islam dan Filsafat

http://ejournal.iainsurakarta.ac.id/index.php/al-araf

ISSN: 1693-9867 (p); 2527-5119 (e)

DOI: $10.22515 /$ ajpif.v14i2.945

\section{HERMENEUTIKA JORGE J.E. GRACIA SEBAGAI ALTERNATIF TEORI PENAFSIRAN TEKSTUAL ALQUR'AN}

Syamsul Wathani

UIN Sunan Kalijaga, Yogyakarta

\begin{tabular}{l}
\hline \\
\hline Keywords: \\
Alnash, \\
Hermeneutics \\
of text meaning, \\
and Textual \\
interpretation \\
paradigm. \\
\hline
\end{tabular}

\begin{abstract}
Abstrak
Artikel ini membahas konsep hermenutika Jorge J.E. Gracia sebagai gagasan alternatif teori penafsiran tekstual Alqur'an. Pembahasan difokuskan pada tiga poin utama, (i) narasi tekstualitas Alqur'an sebagai obyek penafsiran,(ii) hermeneutika Gracia dalam memaknai teks dan (iii) menata paradigma tafsir tekstual terhadap Alqur'an. Dengan model kajian interpretatif, diawali dengan pemetaan teori pemahaman ala Gracia, kemudian mensistematisasikannya ke dalam rumusan teori, hasil studi menunjukkan: (I) konsep teks Alqur'an (alnash) adalah kesadaran utama. Alqur'an adalah sesuatu yang terbaca/tersentuh (almaktub). Sebagai alnash, Alqur'an memiliki mekanisme teks yang pendekatan ke-tekstualitasan-nya menjadi pintu utama dalam membuka makna. (2) Nalar hermeneutis ala Gracia diarahkan untuk mengatasi kesalahpahaman (bukan pemahaman) dari sebuah teks. Sementara metode the development of textual interpretation untuk menjembatani kesejarahan teks dengan situasi audiens. (3) Paradigma tafsir tekstual merupakan cara pandang terhadap Alqur'an dan penafsirannya, dengan konsep "alnash" sebagai titik tolak, kemudian bekerja dengan menekankan adanya pemahaman di antara teks, audiens, dan konteks.
\end{abstract}

\section{Abstract}

This article discusses the Jorge J.E. Gracia's hermeneutical concept used as an alternative theory of the Qur'anic textual interpretation. The discussion focuses on three main points, (i) the Qur'anic textual narration as the object of interpretation, (ii) Gracia's hermeneutic to interpret the text, and (iii) arranging the Qur'anic textual interpretation paradigm. Based on the interpretive study, started with mapping the Gracia's theory of understanding, and then systematizing it into the theory formulation, the results of the study showed: (1) the concept 
of qur'anic text (alnash) is the ultimate consciousness. The Qur'an is something readable/touchable (almaktub). As an alnash, Qur'an has a text mechanism in which its contextual approach becomes the main gate to open its meaning. (2) The Gracia's hermeneutic logical reasoning is directed to overcome misunderstanding (not understanding) of the text. While the development of textual interpretation method used to bridge between the historical text and the audience's situation. (3) The paradigm of the textual interpretation used as a worldview to look at the Qur'an and its interpretation, with the concept of "alnash" as its starting point, and then working with emphasizing the existing understanding among text, audience, and context.

\section{Pendahuluan}

Persoalan hermeneutika Alqur'an bersifat sui genesis. Satu sisi, ia berkaitan dengan teks dan konteks sosio-historis seorang penafsir, dan pada sisi lain menjadi semakin kompleks ketika diaplikasikan sebagai sebuah metode yang digunakan untuk melakukan pembaharuan pemikiran terhadap teks agama. ${ }^{1}$ Hermeneutika, sebagai sistem interpretasi masih menjadi polemik dikalangan umat Islam. Ada pihak yang setuju, dan ada pula yang menggugat atau bahkan menolaknya. Pihak yang setuju, umumnya bersikap apresiatif meski tetap disertai dengan sikap kritis, dengan melihat hermenetuika sebagai proses dialektika intelektual yang kreatif dalam memahami teks agama, ${ }^{2}$ atau divine text dalam bahasa Muhammad Syahrur. ${ }^{3}$ Sedangkan pihak yang menggugat dan menolak hermeneutika, cenderung bersikap reaksioner dan apatis. Bahkan terkadang menggunakan cara-cara yang cenderung teologis-dogmatik, sehingga melahirkan tuduhan "pengkafiran" dan "pemurtadan" terhadap pemikir hermeneutis, sebagaimana pernah terjadi pada Nasr Hamid Abu Zayd. ${ }^{4}$

1 Nashr Hamid Abu Zayd, Alquran, Hermeneutik, dan Kekuasaan : Kontroversi dan Penggugat Hermeneutika Alqur'an (Terj) (Bandung: RQiS, 2003$), 7$.

2 Abdul Malik, “TAFSIR ALQUR'AN PARADIGMA INTEGRATIF: STUDI ATAS QIRA'AH ALTHANIYAH MUHAMMAD SYAHRUR," Al-A'raf:Jurnal Pemikiran Islam dan Filsafat XIV, no. 1 (2017): 117-141.

3 Muhammad Syahrur, "The Divine Text and Pluralism in Moslem Societies"," in Hermeneutika Alqur'an Madz̧bab Yogya, ed. Dkk Syamsuddin, Sahiron (Yogyakarta: Islamika, 2003), 257.

4 Nashr Hamid Abu Zayd, Alquran, Hermeneutik dan Kekuasaan : Kontroversi dan AL-A'RAF - Vol. XIV, No. 2, Juli - Desember 2017 
Polemik terjadi dalam banyak elemen. Mulai dari ketika hermeneutika diproyeksikan menjadi sebuah disiplin ilmu untuk memahami teks, sampai pada ketidaksesuaian beberapa elemen hermeneutika dengan 'ulum altafsir sebagai perangkat resmi untuk memahami Alqur'an. Persoalan ontologis hermeneutika dan kaitannya sebagai episteme dalam memahami Alqur'an menjadi pemicu perdebatan. Namun yang perlu dicatat, sebagaimana sifat ilmu-yang berlaku dalam tradisi agama apapun-hermenutika juga disikapi dan dimunculkan oleh beragam tokoh, dengan beragam teori dan pendekatan.

Artikel ini berusaha menjawab polemik tersebut, dengan menjadikan hermeneutika Jorge J.E. Gracia sebagai titik tolak pemaknaan teks. Di antara para penggagas hermeneutika, model heremeutika Gracia memiliki tempat tersendiri. Bahkan bisa dibilang berada dalam kategori aliran hermeneutika moderat. Sebagaimana pemetaan Sahiron Syamsuddin, yang menempatkan Gracia ke dalam aliran tengah-tengah (obyektivis-cum-subyektivis), di antara dua aliran sebelumnya yang obyektifis dan subyektifis. ${ }^{5}$ Kaegori moderat di sini merujuk pada, bahwa hermeneutika Gracia menekankan perlunya keseimbangan antara pencarian makna asal teks, dan peran pembaca dalam penafsiran. Sehingga model hermeneutika Gracia dimungkinkan untuk diaplikasikan dalam ranah pengembangan ilmu Alqur'an dan tafsir.

Gracia memiliki dua karya monumental terkait kajian teks, bahasa, dan pemahamannya, yakni: Text; Ontological Status, Identity, Author, and Audience, dan A Theory of Textuality: The Logic and Epistemology. Karya pertama memuat pemikiran Gracia mengenai teks beserta kompleksitasnya, sementara karya kedua memuat pemikirannya mengenai teori pemahaman (a theory of meaning). Artikel ini lebih fokus pada karya Gracia yang kedua. Dengan pola kajian analisis interpretatif-strukturasi, artikel ini tidak akan menganalisis isi semua karya Gracia secara eksploratif, tetapi lebih pada

\footnotetext{
Penggugat Hermeneutika Alqur'an (Terj), 7-8.

5 Sahiron Syamsuddin, Hermeneutika dan Pengembangan Ulumul Quran (Yogyakarta: Pesantren Nawesea Press, 2009), 26-27.
} 
model interpretatif, dimana akan dipetakan beberapa poin pemikiran Gracia mengenai teori pemahaman, serta mensistematisasikan gagasan mengenai teori pemahaman tersebut-dalam sebuah rumusan teori-untuk digunakan sebagai teori interpretasi Alqur'an.

Dengan demikian, artikel ini akan beroperasi pada tiga pembahasan: (1) mengenai posisi penafsiran Alqur'an sebagai teks; (2) interpretasi teks atau teori pemaknaan teks menurut Gracia; dan (3) kemungkinan teoritis pemahaman teks Gracia sebagai teori interpretasi tekstual Alqur'an. Core study artikel ini menekankan pada kajian teoritis, bukan praksis secara lansung pada penafsiran Alqur'an. Dalam arti, melihat kemungkinan teori pemaknaan teks ala Gracia dengan alur teori tafsir yang berlaku di dunia Islam.

Dengan fokus pada beberapa pembahasan tersebut, artikel ini akan dapat memberikan pemahaman mengenai pola dan alur interpretasi Alqur'an sebagai teks. Menarasikan teori intepretasi tekstual Alqur'an dalam tradisi Islam, menganalisis dan merumuskan dengan baik teori pemaknaan teks ala Gracia, serta mengkomparasikan dan melihat kemungkinan teori pemaknaan teks ala Gracia untuk digunakan dalam memahami Alqur'an. Sehingga model hermeneutika Gracia ini dapat menjadi "pembacaan alternatif” teori interpretasi Alqur'an di era kontemporer.

\section{Biografi Intelektual Jorge J.E. Gracia}

Jorge J.E. Gracia dilahirkan di Kuba pada tahun 1942. Ia adalah seorang profesor dalam bidang filsafat di University at Buffalo, New York. Sejarah intelektualitas filsafatnya dimulai dari undergraduate program di Wheaton Collage (1965), kemudian melanjutkan ke graduate program di University of Chicago (1966), dan meraih gelar doktor filsafat dari University of Toronto pada tahun $1971 .^{6}$

Melihat perjalanan intelektualnya, Gracia menjadi salah satu

6 Sahiron Syamsuddin, Hermeneutika dan Pengembangan Ulumul Quran, 52 
bermenian yang memilih core study dalam bidang yang terkait dan terintegral, antara lain: metafisika/ontology, historiografi filosofis, filsafat bahasa/ hermeneutika, dan filsafat skolastik. Dengan core study ini, ia menjadi professor di Universitas Buffalo, sekaligus menjadi filosof terkenal di Amerika. Dilihati dari jenjang pendidikannya, Gracia adalah orang yang memiliki pengetahuan mendalam di bidang filsafat, karena ia sangat konsisten menekuni bidang ini. Bahkan dirinya dapat dikatakan sebagai salah satu filusuf kontemporer.

Disamping menjadi pengajar filsafat, Gracia juga aktif di berbagai organisasi yang terkait dengan bidang kajiannya. Selain itu, Gracia juga memberikan perhatian terhadap masalah-masalah etnisitas, identitas, nasionalisme, dan lain-lain. Selain itu, Gracia juga mengkaji bidang metafisika dan hermeneutika, terlihat dari hasil penelitian yang pernah dilakukannya. $^{7}$

Hingga pertengahan tahun 1980, Gracia sebenarnya tidak terlalu tertarik pada kajian hermeneutika. Baginya, hermeneutika merupakan teori interpretasi, di mana term ini digunakan pada begitu banyak kajian saat ini. Kehadiran Peter Here, sahabat Gracia yang juga ahli bahasa, pada tahun1980-an dalam sebuah konferensi di Buffalo terkait isu historiografi, mulai membuatnya tertarik mengkaji hermeneutika secara mendalam. Selama bergelut dengan sejarah filsafat, Gracia belum benar-benar secara eksplisit mengkonfrontasi isu-isu historiografi.

Konteks historiografi inilah yang tampak dalam konsep Gracia mengenai author dalam karyanya, Text; Ontological Status, Identity, Author, and Audience. Dalam karya ini, Gracia memunculkan beberapa ide dan pemetaan mengenai kepengarangan. Di Indonesia, beberapa teori mengenai "kepengarangan teks" juga digunakan dalam mengkaji hadith, terutama masalah tabrif atau mengetahui dari mana sebuah redaksi hadith mulai berubah. Sedangkan karya kedua, A Theory of Textuality: The Logic

7 "Biografi Gracia," University at Buffalo, New York. 
and Epistemology ini sebagai lanjutan dari karya pertama, yang di dalamnya memuat ide-ide Gracia terkait dengan teori pemaknaan teks.

\section{Alqur'an dalam Persepsi Tekstualitas}

Persepsi mengenai Alqur'an sangat dipengaruhi oleh horizon keilmuan, serta bangunan hasil tafsir/teori tafsir yang dibangun oleh mufasir. Cara pandang terhadap Alqur'an memiliki poin penting dalam melahirkan corak tafsir. Sebagian tokoh memandang Alqur'an sebagai nilai yang berjalan, sebagai teks yang baku, sebagai qanun yang qath'i, sebagai dokumen sosial, dan lain sebagainya. Dalam pendahuluannya terhadap Mafhum Alnash, Nasr Hamid Abu Zayd menyebut bahwa peradaban Arab adalah peradaban teks, dan Alqur'an merupakan teks sentral dalam sejarah peradaban Arab. ${ }^{8}$ Dengan demikian, dapat dipahami mengapa Alqur'an menjadi salah satu teks paling berpengaruh di tanah Arab, bahkan bagi dunia secara global.

Persepsi mengenai Alqur'an melahirkan teori tafsir tersendiri, yang kemudian menjadi ke-khas-an bagi seorang mufasir dalam mencari makna. Sehingga para mufasir pun akan memiliki konsepsi tersendiri setelah melakukan penafsiran. Dalam bentuk teks, Alqur'an pertama kali dikenal dengan pencarian makna ayat melalui ayat-ayat lainnya. Adakalanya sebuah ayat memiliki makna yang ambigu, sehingga diperlukan pendukung yang dapat ditemukan pada ayat-ayat lainnya. Hal ini menjadi penguat bagi pentingnya menempatkan tekstualitas Alqur'an sebagai kesadaran awal, bahwa Alqur'an adalah teks yang tersentuh.

Tekstualitas Alqur'an sebenarnya dapat dipahami dari komposisi yang dimilikinya, ia adalah hurf, alqur'an, alkitab ayat, kalimat, dan alrisalah. Oleh sebab itu, Nasr Hamid memandang Alqur'an sebagai objek kajian, layaknya kajian terhadap teks-teks umum lainnya. Nasr Hamid menegaskan, bahwa teks (nash) dikonsepsikan berbeda oleh aliran kalam

${ }^{8}$ Nasr Hamid Abu Zayd, Mafhum Alnass: Dirasat fi 'Ulum Alquran (Beirut: Almarkaz Alsaqafi Al'arabi, 2000), 6-7. 
pada abad awal Islam. ${ }^{9}$ Nasr Hamid menegaskan bahwa posisi sebagai teks yang memiliki mekanisme teks, sehingga memahami Alqur'an tidak selalu didekati dengan cara teologi-mistik, tetapi juga perlu diperhatikan realitas yang menuntut pengkajian Alqur'an (nash) secara rasional-ilmiah. Posisi ini menentukan sikap banyak pemikir Islam, bahwa Alqur'an membutuhkan ilmu di atas keyakinan semata.

Persepsi Alqur'an sebagai teks memiliki banyak konsepsi: sebagai teks biasa (Qur'an as text), sebagai literatur keagamaan (Qur'an as literature), dan sebagi teks suci (Qur'an as sacret text) sehingga melahirkan Alqur'an dan teori tekstualitas mengenainya. Mengakui secara natural Alqur'an sebagai kitab (scripture) adalah kesadaran awal, baru kemudian membahas prinsip kebahasaan (ketekstualan-semantis) yang lebih bersifat metodis dalam memahaminya sebagai teks. Namun teori teks semata tampak tidak adil bagi pemikir lain. Karena Alqur'an sebagai divine writing (kitab wahyu) bersifat interpenetrated dan cair. Oleh sebab itu, pendekatan yang menekankan bahwa Alqur'an adalah buku atau tulisan, menjadi tidak adil jika dijadikan satu-satunya pendekatan, mempertimbangkan kerumitan pemaknaan dan penjelasan Alqur'an terhadap kondisinya sebagai kitab wahyu tersebut.

\section{Hermenutika Teks Gracia}

Kata "hermeneutika" diambil dari bahasa Yunani, "hermeneuein" yang berarti "menjelaskan" (to explain). ${ }^{10}$ Dalam operasioanlnya, hermeneutika bisa dipahami sebagai proses mengubah sesuatu, dari situasi dan makna yang tidak dapat diketahui, menjadi makna yang

${ }^{9}$ Konsepsi perdebatan klasik aliran kalam Islam mengenai Alqur'an lihat : Nasr Hamid Abu Zayd, Alnashsh, Alsulthah, Alhaqiqah: Alfiker Aldini bain Iradat Alma'rifat wa Iradat Alhaiminat (Beirut: Almarkaz Altsaqafi Al'arabi, 1995), 68-69.

${ }^{10}$ Fahruddin Faiz, Hermeneutika Alqur'an; Tema-Tema Kontroversial (Yogyakarta: Elsaq, 2005), 4. 
dapat dimengerti. ${ }^{11}$ Jika dikaitkan dengan teks keagamaan (divine text), hermenutika dalam bahasa Komarudin Hidayat, membumikan "bahasa langit" menjadi bahasa manusia yang menggunakan "bahasa bumi". ${ }^{12}$ Definisi hermeneutika ini-sebagai ilmu interpretasi- ${ }^{13}$ sejalan dengan definisi Alzarqani mengenai tarjamah Alqur'an, yaitu: memindahkan/ mengubah kalam, dari satu bahasa ke bahasa lain (naqlu alkalam min lughah ila lughah ukhra). ${ }^{14}$

Problem hermeneutik selalu mempersoalkan jarak ruang dan waktu, antara pengarang dan pembaca. Dalam rentang jarak tersebut, besar kemungkinan pembaca tidak bisa memahami secara jelas kata-kata, istilahistilah, dan kalimat-kalimat yang dibuat oleh pengarang. Kekeliruan adalah suatu hal yang selalu membayangi dalam setiap proses penafsiran. Karena persoalan jarak itu pula, seseorang dapat berpeluang memanipulasi makna teks sesuai dengan keinginan subjektifnya.

Sering terjadi pada proses interpretasi teks Alqur'an, dimana tidak jarang seorang penafsir dengan sengaja atau tidak, telah 'memanipulasi' makna teks Alqur'an demi kepentingan diri sendiri atau kelompoknya. Sehingga interpretasi menjadi bersifat subjektif-ideologis-tendensius. ${ }^{15}$ Untuk menghindari hal ini, Gracia menawarkan konsep dan penataan kembali paradigma mengenai teks dan upaya untuk memahaminya. ${ }^{16}$

11 Khamdan, dkk., Studi Alqur'an: Teori dan Metodologi (Yogyakarta: Idea Press, 2011), 163.

12 Komaruddin Hidayat, Memahami Bahasa Agama: Sebuah Kajian Hermeneutik (Jakarta: Paramadina, 1998).

13 Khamdan, dkk., Studi Alqur'an: Teori dan Metodologi, 166.

14 Muhammad Abdul Azim Alzarqani, Manabil AlIrfan fi Ulum Alqur'an (Beirut: Dar Alkutub Alilmiyah, 2010), 328-329.

${ }^{15}$ Nasr Hamid Abu Zayd, "Naqd Khitab Addin," in Hermeneutika dan Pengembangan Ulumul Qur'an, ed. Syahiron Syamsuddin, 1992, 55-56.

16 Gracia bukanlah orang yang pertama menawarkan ide ini. Jauh sebelumnya, beberapa ulama' klasik seperti Ibnu Qutaybah telah menawarkan teori pemaknaan (teori lafdzi), yang mencakup leksikan-struktural dan juga teori maknawi yaitu teori makna. Teori ini lahir sebagai respon dari ragam gaya tutur Alqur'an itu sendiri. Lihat. M. Nur Kholis Setiawan, Alqur'an Kitab Sastra Terbesar (Yogyakarta: Elsaq Press, 2006), 193-195. 
Dengan latar sejarah intelektual yang berbeda, ide Gracia ini khas bila dibandingkan dengan kebanyakan pemikir hermeneutika lainnya. Jika karya Syahrur disebut khas dengan analisis dari latar keilmuan sains dalam memahami dan merumuskan teori interpretasi Alqur'an pembacaan modern (qira'ah al-Mu'ashirah), ${ }^{17}$ maka Gracia hadir dengan penguasaan historiografi dan filsafat. Penguasaan ini yang menjadi basis argumentasi lahirnya dua karya Gracia. Berikut di antara beberapa ide Gracia terkait interpretasi teks:

Pertama, status interpretasi. Bagi Gracia, fungsi pokok dari teks adalah menyampaikan makna kepada audiens. Produksi pemahaman bagi audiens merupakan hal penting (urgent). Pemahaman audiens terhadap teks beragam dan bervariasi, antara satu dengan yang lainnya. Oleh karena itu, tidak mengherankan jika dalam beberapa kasus, banyak ditemukan ketidakpahaman (misunderstanding). ${ }^{18}$

Bagi Gracia, teks merupakan entitas sejarah yang terbentuk dalam situasi tertentu yang melingkupi pengarangnya. Oleh karena itu, seorang penafsir teks memiliki dua tugas: satu sisi sebagai historian yang mencoba kembali ke makna sejarah, dan di sisi lain menjadi seorang philoshoper yang berusaha mencari dan menciptakan makna. ${ }^{19}$

17 Muhammad Syahrur, Alkitab wa Alquran: Qira'ah Mu'ashirab (Damaskus: Alahali, 1990), 30-32.

18 Jorge J. E. Gracia, A Theory of Textuality: The Logic and Epistemology (Albany: State University Of New York Press, 1995), 147-148.

19 Karena Itu Sahiron Syamsudin memasukkan Gracia pada Aliran ketiga, aliran Obyektivis-cum-subyektivis atau aliran tengah-tengah antara dua aliran hermeneutika lainnya. Pemikiran yang masuk pada kategori ini adalah pemikiran Gadamer dan Gracia. Aliran ini memberikan keseimbangan antara pencarian makna asal teks dan peran pembaca dalam penafsiran. Karena itu penekanan factor internal dan eksternal seorang pengarang dan pembaca menjadi penting dikaji dalam aliran ini. Baik Gadamer maupun Gracia, keduanya mengkritik nalar hermeneutik yang dibangun oleh Schleiermacher dan Dilthey dalam masalah teks. Menurut mereka, interpretasi tidak sama dengan mengambil suatu teks, lalu mencari arti teks sebagaimana dimaksud pengarang. Sebaliknya, arti suatu teks tetap terbuka sesuai dengan horison penafsir. Komaruddin Hidayat, Memahami Bahasa Agama: Sebuah Kajian Hermeneutik. Sahiron Syamsuddin, Hermeneutika dan Pengembangan Ulumul Quran, 44-52 
Kenyataan yang perlu dibangun dalam jiwa penafsir teks, menurut Gracia adalah kesadaran bahwa seseorang tidak bisa mengakses langsung kepada makna. Ia hanya bisa mengakses kepada teks (entitas makna) yang menjadi wadah dari ide dan makna sang pengarang. ${ }^{20}$ Narasi interpretasi ini merinci elemen-elemen penting dalam interpretasi, yang meliputi kesejarahan, kepengarangan, konteks pengarang, konteks audiens, konteks penafsir, dan lain-lain. Kesadaran seorang penafsir menjadi penting, karena hal tersebut yang akan mempengaruhi langkah-langkah dalam menafsirkan. $^{21}$

Fenomena yang sering terjadi dalam memahami teks menurut Gracia, seringkali audiens menggunakan cara yang berbeda dari cara yang digunakan oleh pengarang historis dalam memahami teks. Akibatnya, terjadi semacam ketidakpahaman (misunderstanding). Padahal dalam memahami teks, audiens tidak mempunyai akses langsung ke pemahaman sang pengarang historis. Sehingga dapat dipastikan mustahil, jika pemahaman audiens terhadap teks itu mempunyai kesamaan dengan sang pengarang historis. Kesadaran ini akan membuat ruang klaim penafsiran menjadi hilang dengan sendirinya. Ide Gracia dalam menjawab problem ini adalah merumuskan beberapa hal mengenai sifat pemahaman dan relasinya dengan makna, jumlah pemahaman dan keterikatan pemahaman dengan teks, serta keterkaitan pemahaman terhadap identitas tekstual. ${ }^{22}$

Gracia menawarkan metode "the development of textual interpretation" yang mencoba menjembatani antara keadaan kesejarahan teks dengan keadaan audiens pada masa sekarang, beserta implikasinya. Gracia memberikan pandangan bahwa ada tiga (3) faktor yang membentuk dan saling bekerjasama dalam sebuah rangkaian interpretasi, antara lain: pertama, teks yang akan ditafsirkan (interpretandum) yang meliputi kesejarahan teks. Kedua, penafsir (interpreter) adalah pelaku atau orang yang akan melakukan

${ }^{20}$ Jorge J. E. Gracia, A Theory of Textuality: The Logic and Epistemology, 147-148.

${ }^{21}$ Jorge J. E. Gracia, A Theory of Textuality: The Logic and Epistemology, 101.

22 Jorge J. E. Gracia, A Theory of Textuality: The Logic and Epistemology, 101. 
pencarian makna historis teks dan akan membentuk makna baru beserta implikasianya dengan panduan fungsi interpretasi. Ketiga, tambahan makna (interpretans) yang merupakan kreasi dari interpreter, yang pada akhirnya menjadi gabungan dari interpretandum dan interpretans, dan inilah yang dinamakan penafsiran. ${ }^{23}$

Kedua, pemahaman dan makna. Dalam kitab tafsir klasik dan ilmu tafsir, tafsir selalu didefinisikan dengan makna dasar menyingkap dan menjelaskan (alkasyfu wa albayan), ${ }^{24}$ yang kemudian secara praksis melahirkan tiga (3) aktivitas menafsirkan Alqur'an, yakni: memahami (alfahm), menjelaskan (albayan), dan mengeluarkan makna (istikhraj). Beberapa pengertian ini menjadi pilar dan pondasi kuat dalam penafsiran Alqur'an. Menurut Gracia, pemahaman tidak sama dengan makna. Pemahaman merupakan aktifitas mental ketika seseorang yang sedang memahami sesuatu, dimana dalam konteks sebuah teks, ia adalah makna. Sedangkan makna teks tidak memerlukan aktifitas mental, dan karenanya tidak identik dengan pemahaman. Meskipun pemahaman adalah sebuah aktifitas, akan tetapi di dalamnya terdiri dari sekelompok aktifitas (a series group of acts) atau berbagai aktifitas dalam waktu bersamaan. Gracia mengatakan:

"Understand is not however, the some as meaning. Understanding is a kind of a mental act where by one grasps something, which in the case of texts is their meaning". (Pemahaman tidaklah sama dengan makna, pemahaman merupakan aktivitas mental ketika seseorang sedang memahami sesuatu, di mana dalam konteks teks adalah makna). ${ }^{25}$

Ungkapan di atas menjelaskan, bahwa 'memahami' merupakan sebuah aktivitas mental yang berusaha menggali dan mendapatkan makna dari sebuah teks. Memahami berarti memutar psikologi dan karakter personal dalam menafsirkan, sebelum hasil penafsiran tersebut di-publish ke ranah publik. Adapun albayan (dalam bahasa Gracia adalah

${ }^{23}$ Jorge J. E. Gracia, A Theory of Textuality: The Logic and Epistemology, 149-150.

24 Muhammad Husein Azzahabi, Attafsir wa Almufassirun (Cairo: Maktabah Wahbah, n.d.), 1-12.

${ }^{25}$ Jorge J. E. Gracia, A Theory of Textuality: The Logic and Epistemology, 103. 
"explain") merupakan langkah selanjutnya setelah memahami (fahm). Setelah memahami makna teks, seorang penafsir harus menjelaskan makna teks, baik dalam bentuk tulisan ataupun suara (speaking form) dengan menggunakan sebuah metode dan memberikan tambahan makna (additional information) serta analisis. Tawaran Gracia inilah yang disebut dengan teori historical function dan meaning function of interpretation. ${ }^{26}$ Terma istikhraj (take out) telah disempurnakan maknanya oleh Gracia dalam teori implicative function of interpretation. ${ }^{27}$

Bagi Gracia, membedakan pemahaman dan makna penting untuk dilakukan. Pembedaan ini akan memperjelas, bahwa dalam memahami teks tidak dapat direduksi dengan pemahaman sang pengarang, ataupun suatu keterangan yang berkaitan dengan pengarang. Oleh karena itu, memahami teks bukan memahami sesuatu yang berhubungan dengan aktifitas yang dilakukan oleh pengarang teks ketika ia menghasilkan teks, atau memahami tentang sesuatu yang berkaitan dengan diri pengarangnya.

Aktifitas pemahaman ini terfokuskan pada makna teks, dan bukan pada sang pengarang dan aktifitas sang pengarang dalam memahami teks. Karena dalam memahami teks, dapat dimungkinan audiens memilih cara yang berbeda dengan sang pengarang, dimana sang pengarang sendiri tidak mengantisipasinya. Pemahaman audiens sering kali berbeda, bahkan berseberangan dengan pemahaman sang pengarang historis. Maka bagi Gracia, pemahaman adalah aktivitas orang per orang yang tidak bisa diseragamkan. Dari sinilah muncul pemahaman yang beragam dan bervariasi dari setiap orang yang mencoba memahami sebuah teks. Persoalan terkait variasi pemahaman terhadap suatu teks, merupakan bukti nyata dari konsep teks sebagai aktifitas mental yang terjadi di dalam pikiran siapapun yang memahami teks. Jika hal ini terjadi, maka hasil dari pemikiran dan aktifitas mental ini akan menghasilkan beberapa pemahaman. Seperti

${ }^{26}$ Jorge J. E. Gracia, A Theory of Textuality: The Logic and Epistemology, 155-157.

${ }^{27}$ Jorge J. E. Gracia, A Theory of Textuality: The Logic and Epistemology, 160-161. 
pemahaman pengarang historis dan audiens yang terlibat dalam aktifitas mental, dimana mereka memahami teks.

Gracia mendetilkan dengan konsep intensional dan ektensional dalam aktifitas memahami teks. Konsep ekstensional terkait pada aktifitas individu dalam memahami, sementara konsep intensional berkaitan pada makna yang dipahami melalui aktifitas tersebut. Oleh karena itu, seseorang dapat mengatakan aktifitas pemahaman secara intensional, karena apa yang dipahami melalui aktifitas tersebut adalah makna yang sama, tetapi secara ekstensional berbeda. Karena mereka secara individu berbeda dalam aktifitas pemahaman.

Dalam hermeneutika pemaknaan teks, tiga elemen yang terlibat dalam membangun makna mempunyai dunianya sendiri. ${ }^{28}$ Pemahaman terhadap teks bagi Gracia bukanlah memahami teks itu sendiri, tetapi pemahaman terhadap makna yang terkandung di dalam teks. Teks tidak dapat disamakan dengan makna. Karena tiga (3) elemen tersebut adalah entitas yang terpisah, yang akan digerakkan semua dalam memahami teks: (a) teks yang harus dipahami atau pemahaman terhadap makna yang dikandung teks; (b) audiens yang memahami teks; dan (c) aktifitas dalam memahami makna yang terkandung di dalam teks. ${ }^{29}$

Ketiga, elemen-elemen interpretasi teks. Kompleksitas teks dalam definisi Gracia di atas, membuat beberapa elemen mengenainya menjadi hal yang tidak terpisahkan. Bagi Gracia, teks memiliki beberapa elemen interpretasi yang perlu dipahami, antara lain: (1) pengarang, sebagai pihak yang membatasi makna teks, sebab ia adalah pembuat teks itu sendiri. Seorang pengaranglah yang menyusun dan meyeleksi tandatanda, sehingga terbentuk sebuah teks. Melalui media teks, pengarang menyampaikan makna yang spesifik kepada audiens. Pengarang tidak hanya bertangungjawab pada pemberian makna entitas yang mendasari teks yang

\footnotetext{
${ }^{28}$ Komaruddin Hidayat, Memahami Bahasa Agama, 1.

${ }^{29}$ Jorge J. E. Gracia, A Theory of Textuality: The Logic and Epistemology, 107.
} 
digunakan, tetapi juga pada makna itu sendiri dan bertanggungjawab pada teks yang terbentuk. ${ }^{30}$ Teks tidak akan pernah ada tanpa pemahaman sang pengarang historis terhadap makna yang ingin disampaikan melalui entitas-entitas yang membentuk teks.

Sekalipun ia yang melahirkan dan membentuk entitas teks, pengarang bukanlah satu-satunya penentu dari makna teks. Ketika teks dilepas, maka audiens akan melihat pengarang adalah historis, penyusun entitas yang berada dalam kemapanan bahasa dan budaya tertentu. Pengarang adalah penyusunan tanda-tanda yang mengikuti aturan-aturan yang telah mapan dalam kehidupan masyarakat tertentu. Pengarang bertanggungjawab atas teks yang dibuat pada poin sebagai author, namun peran budaya dan lokalitas teks menjadi sorotan penting bagi para reader. ${ }^{31}$

Jika dikaitkan dalam konteks Islam, Alqur'an adalah wahyu dari Allah. Dalam hal ini, Allah sebagai pengarang, yang tentu mempunyai maksud dan tujuan tertentu ketika menurunkan Alqur'an kepada umat manusia. Akan tetapi, membatasi makna Alqur'an dengan membatasi maksud dari pengarang adalah sesuatu yang tidak mungkin. Karena Alqur'an ditulis dalam bahasa manusia (Arab) yang telah mempunyai aturan-aturan gramatikal sendiri. Proses pewahyuan yang berangsurangsur dan peristiwa yang terjadi dalam konteks saat itu, membuat makna

${ }^{30}$ Jorge J. E. Gracia, A Theory of Textuality: The Logic and Epistemology, 114-115.

31 Jorge J. E. Gracia, A Theory of Textuality: The Logic and Epistemology, 115-116. Hal demikian melahirkan apa yang dikenal sebagau reader-respone. Sahiron Syamsuddin menempatkan reader-response sebagai aliran hermeneutika subjektifis. Teori ini yang berkembang dalam ranah literary studies ini mengenal sejumlah istilah kunci seperti reader, reading, text dan piece of writing. Reader adalah pembaca, reading adalah aktifitas membaca, dan text adalah pengalaman pembaca ketika ia melakukan pembacaan terhadap piece of writing. Oleh sebab itu, dalam reader-response, sebuah teks hanya bermakna apabila ia dibaca, apabila si pembaca berpartisipasi aktif dalam pemaknaan suatu tulisan (piece of writing). Makna yang akan dihasilkan oleh pembaca akan sesuai dengan pengalaman masing-masing pembaca, yang dipengaruhi banyak aspek seperti gender, kelas sosial, dan lingkungan sosio-kultural secara luas. Makna, oleh sebab itu, tidak berada di halaman, tinta di atas kertas, bahkan juga tidak di pikiran pembaca, akan tetapi di pikiran pembaca selama dan setelah ia melakukan aktifitas membaca. Fadli Lukman, Telaah Pemikiran Daniel A. Madigan terhadap Alqur'an, 2013, 6.

AL-A'RAF - Vol. XIV, No. 2, Juli - Desember 2017 
dan pemahaman tentang ayat-ayat yang tertulis terbatasi pada konteks saat itu. Dengan demikian, sang pengarang tidak mempunyai otoritas penuh terhadap makna dan pemahaman yang akan dihasilkan, tetapi pengarang tetap mempunyai pengaruh terhadapanya. ${ }^{32}$

(2) Audiens. Jika sang pengarang tidak menentukan makna dari sebuah teks, dapat saja audiens juga tidak menentukan maknanya. ${ }^{33}$ Dalam hal ini, audiens mempunyai posisi yang sama dengan pengarang, dalam konteks sama-sama menghadapi teks, dan sama-sama mengahadapi aturan-aturan umum dari entitas pembentuk teks. Meski di satu sisi audiens dimungkinkan lebih mengetahui makna teks dengan baik dari pada pengarang historis, namun di sisi lain audiens bukanlah pencipta teks dan penyusunnya. Sehingga audiens juga menjadi faktor yang membatasi makna teks. ${ }^{34}$

(3) Konteks yang berada dalam teks dan makna teks. Konteks menjadi faktor yang turut serta menentukan makna. Entitas teks bisa saja mempunyai makna berbeda jika berada dalam suatu konteks yang berbeda. Jika pengarang dan audiens dipisahkan dari konteks, mereka sama-sama tidak dapat menentukan makna. Jika pengarang dan audiens dipisahkan dari konteks, maka kelompok entitas yang membentuk teks tidak bermakna. ${ }^{35}$

Implikasi terpisahnya teks dari pengarang dan konteks situasi sosial yang melahirkannya, menjadikan teks tidak komunikatif dengan keadaan sosial yang melingkupi pembaca. Tekadang, sebuah teks diciptakan sebagai respon terhadap realitas sosial yang sedang dihadapi. Karenanya, menjadi sangat penting mempertimbangakan konteks (sebagai batasan makna), baik yang melingkupi pengarang, teks, dan pembacanya. Konsekuensinya adalah menjadi sangat masuk akal jika teks-teks keagamaan yang ditulis

\footnotetext{
32 Nadia, "Hermeneutika Jorge J.E Gracia" (UIN Sunan Kalijaga, 2013).

33 Jorge J. E. Gracia, A Theory of Textuality: The Logic and Epistemology, 116.

34 Nadia, "Hermeneutika Jorge J.E Gracia", 55.

35 Jorge J. E. Gracia, A Theory of Textuality: The Logic and Epistemology, 117.
} 
oleh ulama yang tinggal di daerah perkotaan akan berbeda konten dan semangatnya, jika dibandingkan dengan teks-teks keagamaan yang ditulis oleh ulama yang hidup di daerah pedesaan. ${ }^{36}$

(4) Masyarakat dan bahasa. Dua entitas ini menjadi pertimbangan dan faktor yang menentukan batasan makna teks. ${ }^{37}$ Bahasa yang digunakan di dalam teks merupakan hasil dari suatu masyarakat tertentu. Namun mereka bukanlah penguasa makna dari teks. Teks ada di dalam bahasa, dimana batas makna tekstual dapat ditemukan. Namun bahasa itu sendiri tidak dapat dianggap sebagai pengatur batas-batas makna teks dengan beberapa alasan: pertama, karena makna teks yang menyusun sebuah bahasa juga tergantung pada konteks. Sedangkan konteks tidak selalu bermakna linguistik atau tekstual. Kedua, bahasa mungkin berisi teks dan maknanya dalam jumlah yang tidak terbatas, tetapi hal ini tidak berarti bahwa bahasa berisi teks yang aktual (yang sebenarnya) atau makna tekstual. ${ }^{38}$

Bahasa tidak hidup, bahasa hanya berfungsi selama pengguna menggunakannya. Jadi pengguna bahasa bertanggungjawab untuk pengembangan teks dari bahasa. Peran penguna bahasa sangat penting, dimana pada perubahan konstan yang dilakukan oleh pengguna bahasa. Dari sinilah, bahasa sebagaimana teks tergantung kepada siapa yang menggunakan dan memahaminya. Oleh karenanya, tidak bisa secara eksklusif bertanggungjawab terhadap teks dan batas-batas makna teks. ${ }^{39}$

(5) Teks. Salah satu pandangan yang lazim terkait dengan persoalan ini adalah bahwa batas makna teks secara eksklusif ditentukan oleh teks itu sendiri. Menurut Gracia, teks adalah sekelompok entitas yang berupa tanda, yang dipilih/disusun dan diatur oleh pengarang dalam konteks tertentu untuk menyampaikan makna tertentu kepada audiens. Teks merupakan ciptaan historis dari seseorang yang biasa menggunakan

\footnotetext{
${ }^{36}$ Komaruddin Hidayat, Memahami Bahasa Agama, 133.

37 Jorge J. E. Gracia, A Theory of Textuality: The Logic and Epistemology, 117-118.

38 Jorge J. E. Gracia, A Theory of Textuality: The Logic and Epistemology, 118-119.

39 Jorge J. E. Gracia, A Theory of Textuality: The Logic and Epistemology, 118-119.
} 
bahasa, yang berkembang secara historis untuk berkomunikasi dengan orang lain. Maka teks tidak bisa ditentukan secara eksklusif oleh sang pengarang, audiens, konteks, masyarakat, bahasa, ataupun teks itu sendiri. Sang pengarang memahami teks dan memperoleh pemahaman tertentu, tetapi dengan menulis teks dalam bahasa yang sudah ada, sang pengarang tidak dapat secara eksklusif bertanggungjawab, bahkan terhadap makna yang dipahami terhadap teks yang dimilikinya.

Dalam beberapa kasus, pengarang tidak peduli terhadap makna teks. Audiens sebagai bagian dari masyarakat menggunakan dan mengembangkan bahasa yang digunakan teks, juga mempunyai peran dalam memainkannya meskipun tidak secara eksklusif. Konteks juga menjadi hal penting, sejauh makna teks tergantung pada situasi dan kondisi yang melingkupi teks. Selain itu, teks itu sendiri juga menentukan batasan atas dirinya sendiri. ${ }^{40}$ Maka bagi Gracia, teks itu tidak sebatas yang tertulis dalam sebuah bentuk (form), tetapi ia begitu kompleks. Teks tidak berdiri sendiri, melainkan ia sebuah konstruksi (constuction), kombinasi (combination) dan korelasi (correlation). ${ }^{41}$

\section{Teori dan Fungsi Interpretasi Teks Jorge J.E Gracia}

Pada bagian awal telah dijelaskan adanya keterkaitan tiga elemen tafsir yang ditegaskan oleh Garcia. Bagi Gracia, antara interpretans dan interpretandum memiliki kaitan erat, karena lahirnya interpretans untuk menjelaskan interpretandum. ${ }^{42}$ Dalam menjelaskan teori interpretasinya, Gracia mengemukakan terlebih dahulu apa yang diistilahkan dengan interpreter's dilemma, yakni keadaan dimana seorang penafsir merasakan kekhawatiran, apakah tambahan kata yang diberikan akan membuat audiens semakin paham atau tidak, atau malah tambahan kata itu akan

\footnotetext{
${ }^{40}$ Jorge J. E. Gracia, A Theory of Textuality: The Logic and Epistemology, 4, 119-123.

41 Jorge J. E. Gracia, A Theory of Textuality: The Logic and Epistemology, 7.

${ }^{42}$ Jorge J. E. Gracia, A Theory of Textuality: The Logic and Epistemology, 148.
} 
mendistorsi teks. ${ }^{43}$ Untuk menjawab ini, Gracia memberikan jawaban dengan bangunan fungsi interpretasinya, yakni historical function, meaning function, dan implicative function.

a) Historical function. Gracia menjelaskan tujuan dari penafsir adalah untuk menciptakan pemahaman dibenak audiens kontemporer, terkait tindakan mental yang memunculkan teks pertama kali (historical author), bukan orang yang mengkreasikan teks, melainkan kondisi masyarakat ketika teks itu muncul. ${ }^{44}$

Pandangan ini mengisyaratkan, bahwa seorang penafsir harus mampu menyampaikan apa yang menjadi tujuan dari teks sejarah (historical teks) dengan pemahaman yang sama dengan apa yang diinginkan oleh historical author. Pemahaman yang dimiliki penafsir inilah yang kemudian dibawa pada audiens kontemporer, sebagai satu pemahaman yang didasarkan pada kondisi psikologi historical audience. Dengan kata lain, tujuan penafsir adalah untuk menciptakan pemahaman pada sebuah teks di antara audiens kontemporer, sehingga tugasnya sama sepeti bagaimana historical author dan historical audience dulu menciptakan historical text. ${ }^{45}$

Dari sinilah terlihat, mengapa interpretasi merupakan bagian integral dari pemahaman historical text untuk memahami sebuah teks. Tujannya untuk menjembatani kesenjangan kontekstual, konseptual, budaya, dan sebagainya yang memisahkan teks dimana ia dibaca, didengar, atau bahkan diingat. ${ }^{46}$

Dalam fungsi inilah, dilema seorang penafsir akan hilang atau terjawab. Sebagaimana ditegaskan oleh Gracia, bahwa dalam melakukan penafsiran ada takaran-takaran yang jika sudah dipenuhi, maka tidak perlu lagi ada kekhawatiran. Gracia menyebut hal ini dengan principle of

\footnotetext{
${ }^{43}$ Jorge J. E. Gracia, A Theory of Textuality: The Logic and Epistemology, 155.

44 Jorge J. E. Gracia, A Theory of Textuality: The Logic and Epistemology, 155.

45 Jorge J. E. Gracia, A Theory of Textuality: The Logic and Epistemology, 157.

${ }^{46}$ Jorge J. E. Gracia, A Theory of Textuality: The Logic and Epistemology, 157.
} 
propotional undestanding. ${ }^{47}$ Bangunan interpretasi ini terlihat sebagaimana dalam bagan berikut:

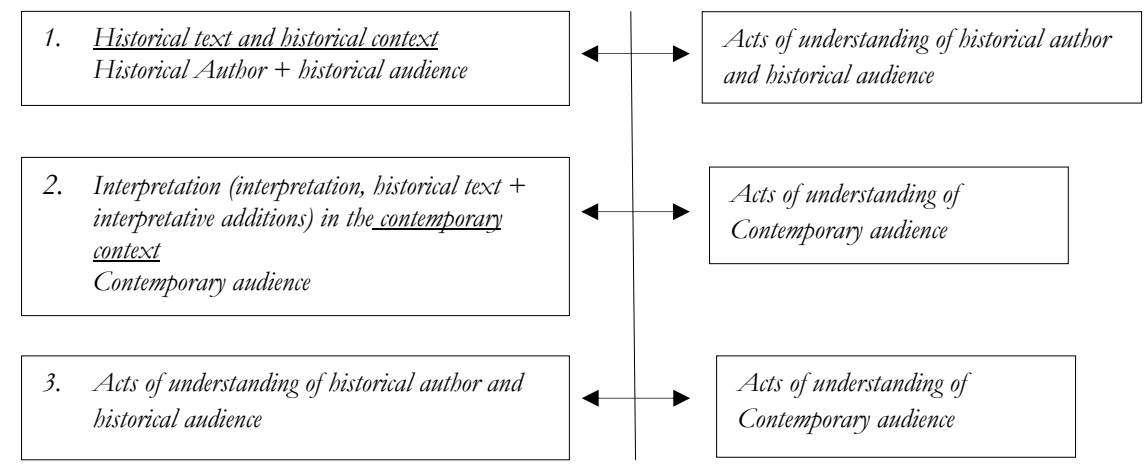

Bagan (1) Bangunan interpretasi teks

b) Meaning function, fungsi perkembangan makna. Gracia menegaskan bahwa fungsi ini bertujuan untuk menciptakan pemahaman di benak audiens kontemporer dan mengembangkan makna dari suatu teks. Terlepas dari apakah pemaknaan tersebut sama atau tidak, dengan apa yang dimaksud oleh author dan audience historis. ${ }^{48}$

Perkembangan makna yang dimaksud adalah suatu pemahaman tambahan dalam menafsirkan suatu teks, karena kondisi yang dialami para penafsir yang berbeda-beda. Akan tetapi, penafsiran tersebut tidak berarti hilang kendali dari makna subtansi teks, melainkan perkembangan makna tersebut hanyalah suatu pengembangan dari makna subtansi yang dikandung oleh teks, sebagai upaya penyesuaian dengan problematika yang sedang dialami para penafsir. Dengan kata lain, menghidupkan teks sesuai dengan permasalahannya. Sehingga seorang mufasir bisa saja menemukan makna lain, asalkan makna tersebut merupakan bagian dari makna keseluruhan sebuah teks (part of the overall teks). ${ }^{49}$

\footnotetext{
${ }^{47}$ Jorge J. E. Gracia, A Theory of Textuality: The Logic and Epistemology, 156

48 Jorge J. E. Gracia, A Theory of Textuality: The Logic and Epistemology, 160.

${ }^{49}$ Jorge J. E. Gracia, A Theory of Textuality: The Logic and Epistemology, 160.
} 
c) Implicative function (fungsi penerapan). Fungsi ini bertujuan untuk memunculkan pemahaman dibenak audiens, sehingga makna dari teks yang ditafsirkan dapat dipahami. Pemaknaan suatu teks dapat dipahami dari tindakan yang dilakukan oleh audiens. Tindakan inilah yang nantinya dipahami sebagai fungsi penerapan. Akan tetapi, antara makna dan penerapan harus dibedakan, walaupun makna dan penerapan terlihat sama. Makna hanya pada ranah konseptual, sedangkan penerapan sudah lebih jauh dari konsep menjadi sebuah tindakan audiens.

Pemahaman tentang makna historis merupakan syarat yang harus dipenuhi untuk memahami fungsi penerapan ini. Seorang penafsir harus konsisten dengan makna yang ada pada teks tersebut menjadi makna yang bisa dipahami oleh audien kontemporer, bukan pemahaman yang subjektif. ${ }^{50} \mathrm{Hal}$ ini tentu tidak mudah bagi seorang penafsir, karena situasi yang dialami seorang penafsir dan kemunculan teks tidak sama. ${ }^{51}$

\section{Alqur'an: Paradigma Tekstual dan Kenisbian Penafsiran}

Memahami Alqur'an sebagai teks memang selalu dipandang sebagi hal yang kaku. Padahal sisi tekstualitas Alqur'an adalah hal yang rumit. Gracia menyimpulkan bahwa bentuk interpretasi ini ada yang tekstual, masih dalam batasan penafsiran teks secara biasa (as act of interpretation with additional information (interpretans) dengan mempertimbangkan aspek kesejarahannya. Ada pula yang non-tekstual, yakni penafsiran yang melampaui teks, sehingga tidak lagi terpaku hanya pada makna dibalik teks dan implikasinya, namun lebih jauh dari itu (produce beyond wording text meaning. Here, the goal of interpretation is to produce understanding not only based on the text with its meaning and implication of text it self but its relation with other texts and aspect beyond.). ${ }^{52}$

${ }^{50}$ Jorge J. E. Gracia, A Theory of Textuality: The Logic and Epistemology, 161.

51 Jorge J. E. Gracia, A Theory of Textuality: The Logic and Epistemology, 161.

52 Jorge J. E. Gracia, A Theory of Textuality: The Logic and Epistemology, 178-179. 
Namun demikian, dua bentuk penafsiran ini menurut Gracia dapat menjadi subyektif dan objektif. Ukuran obyektifnya dilihat dari usaha dan perhatian yang besar dalam menggali kesejarahan teks (bigh attention to interpretandum and historical aspect). Sementara ukuran subyektif adalah sebaliknya, "low attention interpretandum and historical aspect". 53

Bahkan, dengan posisi tafsir tekstual pun, penafsiran tidak memiliki kebenaran tunggal dan anti-kesempurnaan. Dua fungsi penafsiran terakhir menjadi basis penekanan Gracia, bahwa tafsir pasti berbeda antar orang per orang, karena banyak aspek dan faktor pendorong lainnya. ${ }^{54}$ Sebuah tafsir tekstual dapat mencapai puncak paling benar, dengan kesamaan framework dan kultur. Namun hal ini mustahil terwujud, mengingat kondisi faktual yang ada dan yang melingkupi diri mufasir. Bahkan tiga fungsi di atas, bagi Gracia menjadi tolak ukur dalam menentukan sebuah tafsir itu efektif atau tidak. ${ }^{55}$ Gracia tidak menggunakan istilah benar dan salah, karena baginya masing-masing fungsi memiliki nilai kebenaran yang berbeda. ${ }^{56}$

Menurut Gracia, terdapat batas-batas makna dari teks yang akan dipahami. Tetapi batasan makna itu sangat tergantung pada beberapa faktor. Oleh karena itu, teks tidak harus dimengerti maknanya secara sempit. Meskipun makna teks itu terbatas, tetapi batasan-batasan yang ada harus dipahami dalam konteks inti dari makna, bukan dari sesuatu yang mungkin dipahami ketika seseorang mengatakan bahwa ia memahami suatu teks. Menurut Gracia, beberapa faktor yang mungkin dapat mempengaruhi dan menetapkan batas-batas makna di antaranya adalah pengarang, audiens, konteks, masyarakat, bahasa, teks itu sendiri, serta fungsi budaya (cultural fuctions). ${ }^{57}$

\footnotetext{
53 Jorge J. E. Gracia, A Theory of Textuality: The Logic and Epistemology, 178-179.

54 Jorge J. E. Gracia, A Theory of Textuality: The Logic and Epistemology, 163.

55 Nadia, "Hermeneutika Jorge J.E Gracia", 67.

56 Jorge J. E. Gracia, A Theory of Textuality: The Logic and Epistemology, 173.

${ }^{57}$ Jorge J. E. Gracia, A Theory of Textuality: The Logic and Epistemology, 114
} 
Tujuan sebuah interpretasi bagi Gracia, sebagaimana juga Gadamer, tidak hanya sebatas reproduksi makna, tetapi juga produktif dalam melahirkan makna baru. Reproduksi makna menjadi konsekuensi logis, karena setiap mufasir tidak dapat melepaskan diri dari situasi historis dimana ia berada. Karena menjembatani jurang waktu antara penafsir dan pengarang adalah mustahil. Bagi Gadamer, "prasangka" dan "tradisi" penafsir harus diafirmasi sebagai horison historis yang memungkinkan pemahaman terhadap teks. ${ }^{58}$ Begitu pula bagi Gracia, bahwa entitas historis teks dan pengarang harus menjadi acuan utama dalam mengkaji teks, untuk selanjutnya ditafsirkan dengan makna yang lebih relevan. ${ }^{59}$

Peran seorang penafsir yang dilingkupi oleh kultur berbeda satu sama lain, dan selalu berkembang dari zaman ke zaman akan melahirkan pola pemikiran berbeda, sehingga interpretasi terhadap teks suci pun akan berbeda pula. Dari sinilah corak tafsir muncul dan berjalan seiring dengan "kecenderungan" sang penafsir. Dari perspektif ini, maka keberadaan seorang penafsir menjadi parameter atas tafsirannya. Selain itu, parameter persfektif tafsir juga dapat dilihat dari siapa pembaca (reader) dan teksnya itu sendiri $($ text $) .{ }^{60}$

Ahmad Jainuri memberikan tiga (3) paradigma besar dalam tafsir. Pertama, interpretasi yang terfokus pada penulis (an author centered interpretation), dimana interpretasi menjangkau makna di luar teks, menghubukannya dengan konteks geografis, historis, budaya, sosial, politik, dan bahasa. Kedua, interpretasi yang terfokus pada pembaca (an reader centered interpretation), relasi yang dibangun adalah relasi dunia yang ada di depan teks (teks dan masyarakat pembacanya). Ketiga, interpretasi yang terfokus pada teks (text an centered interpretation), mengungkapkan dunia yang ada dalam teks itu, dimana dua hal menjadi tekanannya, narasi teks dan subyek teks itu sendiri. ${ }^{61}$

58 Sahiron Syamsuddin, Hermeneutika dan Pengembangan Ulumul Quran, 44-52.

59 Sahiron Syamsuddin, Hermeneutika dan Pengembangan Ulumul Quran, 55

${ }^{60}$ Ahmad Jainuri, “Teori Interpretasi dalam Persfektif Filsafat Hermeneutika," Mukaddimah 5 (1999): 124-129.

${ }^{61}$ Ahmad Jainuri, “Teori Interpretasi dalam Persfektif Filsafat Hermeneutika," Mukaddimah 5, 124-129. 
Ketika menemukan kesulitan dalam memahami pesan dalam sebuah kitab suci, hermeneutika menjadi alternatif perangkat bedah, disamping teori interpretasi lainnya. Walaupun masih menyisakan dua poros yang bertolak belakang, tetapi kajian hermeneutika semakin berkembang hingga kini. Sebagai sebuah metode interpretasi, hermeneutika sangat besar pengaruhnya bagi keilmuan. Dalam kajian hermenutika sebuah teks akan bermakna apabila ia dibaca, dan apabila si pembaca berpartisipasi aktif dalam pemaknaan teks itu sendiri. Makna yang dihasilkan oleh pembaca pun akan ditentukan oleh pengalaman masing-masing pembaca, yang juga dipengaruhi oleh banyak aspek, seperti gender, kelas sosial, dan lingkungan sosio-kultural secara luas. Makna tidak berada di dalam halaman, tidak di dalam tinta, tidak di atas kertas, bahkan juga tidak dalam pikiran pembaca, akan tetapi di dalam pikiran pembaca selama dan setelah ia melakukan aktifitas membaca. ${ }^{62}$

\section{Penutup}

Dari uraian di atas, setidaknya dapat diambil beberapa kesimpulan, pertama, konsep teks Alqur'an atau Alnash merupakan konsep yang tampak hingga saat ini. Tekstualitas Alqur'an dalam menafsirkan adalah kesadaran utama yang mesti dibangun. Sebab Alqur'an adalah sesuatu yang terbaca/tersentuh (Almaktub). Ke-maktub-an Alqur'an terlihat dari entitas burf, alqur'an, alkitab ayat, kalimat dan alrisalah yang tersusun rapi, khas, dan membedakan dengan teks semasanya maupun teks sebelumnya. Sebagai alnash, alqur'an memiliki mekanisme teks yang pendekatan ketekstualitasannya adalah pintu utama dalam membuka maknanya sebagai teks. Dengan demikian, teks dan makna adalah entitas yang terkait, tetapi juga berbeda.

Kedua, nalar hermeneutis pemaknaan teks ala Gracia diarahkan untuk mengatasi ketidakpahaman (misunderstanding), bukan pemahaman (undestading) dari sebuah teks dengan metode the development of textual

${ }^{62}$ Sahiron Syamsuddin, Hermeneutika dan Pengembangan Ulumul Quran, 26. 
interpretation, guna menjembatani kesejarahan teks dengan keadaan audiens. Teks bagi Graci adalah entitas yang hidup dan menyangkut banyak segi yang perlu dipahami dengan jalur undestanding (albayan), expalin (alfahm) dan implicative (istikhraj). Sebagai teks, Alqur'an adalah entitas yang di dalamnya menyangkut banyak poin untuk yang harus dianalisis, mengingat adanya konteks dan audiens. Elemen teks tersebut adalah entitas yang terpisah dan semua akan digerakkan untuk memahami teks. Teks harus dipahami oleh audiens sebagai aktor yang melakukan aktifitas dalam memahami makna yang terkandung dalam teks.

Ketiga, paradigma tafsir tekstual merupakan cara pandang terhadap Alqur'an dan penafsirannya, dengan konsep “an-nash” sebagai titik tolak, bekerja dengan menekankan pada pemahaman yang baik antara teks, audiens, dan konteks. Konteks di sini adalah konteks teks, bukan konteks yang dipahami dalam tafsir kontesktual. Teks Alqur'an bukan sebatas yang tertulis dalam sebuah bentuk (form), ia begitu kompleks, ia adalah sebuah konstruksi (constuction), kombinasi (combination), dan korelasi (correlation). Dengan demikian, paradigma tafsir tekstual adalah hal yang luas untuk dipahami, dari hanya sekedar tafsir yang kaku, klasik, dan lain sebagainya.

\section{Referensi}

Alzarqani, Muhammad Abdul Azim. Manabil Alirfan fi Ulum Alqur'an. Beirut: Dar Alkutub Alilmiyah, 2010.

Az-Zahabi, Muhammad Husein. Altafsir wa Almufassirun. Cairo: Maktabah Wahbah, n.d.

Faiz, Fahruddin. Hermeneutika Alqur'an; Tema-Tema Kontroversial. Yogyakarta: Elsaq, 2005.

Gracia, Jorge J. E. A Theory of Textuality: The Logic and Epistemology. Albany: State University Of New York Press, 1995.

Hidayat, Komaruddin. Memahami Bahasa Agama: Sebuah Kajian Hermeneutik. Jakarta: Paramadina, 1998. 
Jainuri, Ahmad. "Teori Interpretasi dalam Persfektif Filsafat Hermeneutika." Mukaddimah 5 (1999): 124-129.

Khamdan, dkk. Studi Alqur'an: Teori dan Metodologi. Yogyakarta: Idea Press, 2011.

Lukman, Fadli. Telaab Pemikiran Daniel A. Madigan terhadap Alqur'an, 2013.

M. Nur Kholis Setiawan. Alqur'an Kitab Sastra Terbesar. Yogyakarta: Elsaq Press, 2006.

Malik, Abdul. “TAFSIR ALQUR'AN PARADIGMA INTEGRATIF: STUDI ATAS QIRA'AH ALTHANIYAH MUHAMMAD SYAHRUR." Al-A'raf: Jurnal Pemikiran Islam dan Filsafat XIV, no. 1 (2017): 117-141.

Nadia. "Hermeneutika Jorge J.E Gracia.” UIN Sunan Kalijaga, 2013.

Syahrur, Muhammad. Alkitab wa Alquran: Qira'ah Mu'ashirah. Damaskus: Alahali, 1990.

- "The Divine Text and Pluralism in Moslem Societies"." In Hermeneutika Alqur'an Madæhab Yogya, edited by Dkk Syamsuddin, Sahiron, 257. Yogyakarta: Islamika, 2003.

Syamsuddin, Sahiron. Hermeneutika dan Pengembangan Ulumul Quran. Yogyakarta: Pesantren Nawesea Press, 2009.

Zayd, Nashr Hamid Abu. Alquran, Hermeneutik dan Kekuasaan : Kontroversi dan Penggugat Hermeneutika Alqur'an (Terj). Bandung: RQiS, 2003.

Zayd, Nasr Hamid Abu. Alnashsh, Alsulthah, Alhaqiqah: Alfiker Aldini bain Iradat Alma'rifat wa Iradat Alhaiminat. Beirut: Almarkaz Altsaqafi Al'arabi, 1995.

-. Mafhum Alnass: Dirasatfi 'Ulum Alquran. Beirut: Almarkaz Alsaqafi Al'arabi, 2000.

—. "Naqd Khitab Addin." In Hermeneutika dan Pengembangan Ulumul Qur'an, edited by Syahiron Syamsuddin, 55-56, 1992.

"Biografi Gracia." University at Buffalo, New York. 
